\title{
Influence of slope aspect on the microbial properties of rhizospheric and non-rhizospheric soils on the Loess Plateau, China
}

\author{
Ze Min Ai ${ }^{1,2,3,4}$, Jiao Yang Zhang ${ }^{1,3,4}$, Hong Fei Liu ${ }^{5}$, Sha Xue ${ }^{1,3}$, and Guo Bin Liu ${ }^{1,3}$ \\ ${ }^{1}$ State Key Laboratory of Soil Erosion and Dryland Farming on the Loess Plateau, Institute of Soil and Water Conservation, \\ Northwest A\&F University, Yangling, Shaanxi 712100, People's Republic of China \\ ${ }^{2}$ College of Geomatics, Xi' an University of Science and Technology, Xi' an, Shaanxi 710054, People's Republic of China \\ ${ }^{3}$ Institute of Soil and Water Conservation, Chinese Academy of Sciences \& Ministry of Water Resources, \\ Yangling, Shaanxi 712100, People's Republic of China \\ ${ }^{4}$ University of Chinese Academy of Sciences, Beijing 100101, People's Republic of China \\ ${ }^{5}$ College of Forestry, Northwest A\&F University, Yangling, Shaanxi 712100, People's Republic of China
}

Correspondence: Sha Xue (xuesha100@163.com)

Received: 22 December 2017 - Discussion started: 2 January 2018

Revised: 24 September 2018 - Accepted: 25 September 2018 - Published: 9 October 2018

\begin{abstract}
Slope aspect is an important topographic factor in the micro-ecosystem environment, but its effect on the microbial properties of grassland rhizospheric soil (RS) and non-rhizospheric soil (NRS) remain unclear. A field experiment was conducted at the Ansai Research Station on the Loess Plateau in China to test the influence of slope aspects (south-facing, north-facing, and northwest-facing slopes, all with Artemisia sacrorum as the dominant species) on RS and NRS microbial biomass carbon (MBC) contents, phospholipid fatty acid (PLFA) contents, and the rhizospheric effect (RE) of various microbial indices. Soil samples were collected from the three slope aspects, including rhizospheric and non-rhizospheric region, and analyzed to determine the various related microbial indices. The results showed that MBC content differed significantly among the slope aspects in RS but not in NRS, and the RE for MBC content in the south-facing slope was larger than that in the north-facing slope. RS total, bacterial, and Gram-positive bacterial PLFA contents in the south-facing slope were significantly lower than those in the north- and northwest-facing slopes, and RS Gram-negative bacterial $\left(\mathrm{G}^{-}\right)$and actinomycete PLFA contents in the south-facing slope were significantly lower than those in the north-facing slope. In contrast, NRS total, bacterial, and $\mathrm{G}^{-}$PLFA contents in the north-facing slope were significantly higher than those in the south- and northwestfacing slopes, and NRS fungal and actinomycete PLFA contents in the north- and south-facing slopes were significantly
\end{abstract}

higher than those in the northwest-facing slope. RE for all PLFA contents except fungal in the northwest-facing slope were higher than those in the south-facing slope. Slope aspect significantly but differentially affected the microbial properties in RS and NRS, and the variable influence was due to an evident RE for most microbial properties.

\section{Introduction}

As an important topographic factor, slope aspect can affect the amount of solar radiation received (Selvakumar et al., 2009), and solar radiation influences ecologically critical factors of local microclimates and determines soil temperature, evaporation capacity, and soil-moisture content (Carletti et al., 2009; Bennie et al., 2008). South-facing slopes in the Northern Hemisphere, which receive more solar radiation than north-facing slopes, are typically hot, dry, and subject to rapid changes in seasonal and diurnal microclimates. Northfacing slopes have the opposite pattern and receive the least insolation, are cool, moist, and subject to slow changes in seasonal and daily microclimates (Sariyildiz et al., 2005). Slope aspect can therefore substantially affect soil-moisture content, water budget, and soil temperatures (Sidari et al., 2008; Carletti et al., 2009; Sariyildiz et al., 2005; Dearborn and Danby, 2017). The effect of slope aspect on basic soil properties ( $\mathrm{pH}$, bulk density, and texture), nutrient contents 
(carbon, nitrogen, and phosphorus), microbial biomass, and enzymatic activities have been studied (Ai et al., 2017a; Ascher et al., 2012; Gilliam et al., 2014; Huang et al., 2015; Sidari et al., 2008; Qin et al., 2016; Bardelli et al., 2017; Liu et al., 2017). Previous research indicated that slope aspect markedly affects soil and microbiological properties in micro-ecosystem environments. The results of studies on the impact of slope aspect on the microbiological properties, however, are not consistent. Some studies have shown that north-facing slopes have more microbial biomass carbon (MBC), bacteria, and actinomycetes than south-facing slopes (Ascher et al., 2012; Huang et al., 2015); in contrast, other studies have found that the MBC, fungal, and total phospholipid fatty acid (PLFA) contents in the south-facing slopes were significantly higher than those in north-facing slopes (Huang et al., 2015; Sidari et al., 2008; Gilliam et al., 2014). Gilliam et al. (2014) found that bacterial biomass did not vary with slope aspect. The influence of slope aspect on microbial characteristics has obviously been variable in these studies, and the differences may be caused by the differences in plant species (trees vs. shrubs), soil properties, climatic conditions, and research methods. Previous studies have mainly focused on trees and shrubs, but the influence of slope aspect on grassland soil microorganisms is still unclear, even though the grassland ecosystem is an important component of terrestrial ecosystems.

The rhizosphere is commonly defined as the narrow zone of soil adjacent to and influenced by plant roots (Chen et al., 2002). The rhizosphere contains root exudates, i.e. leaked and secreted chemicals, sloughed root cells, and plant debris (Warembourg et al., 2003). Microbial activity is therefore high in rhizospheric soil (RS) and clearly distinct from the activity in non-rhizospheric soil (NRS) due to differences in nutrient availability, $\mathrm{pH}$, and redox potential (Hinsinger et al., 2009). Microbial content is higher in RS than NRS (Buyer et al., 2002; Marschner et al., 2002), which is known as the rhizospheric effect (RE). The effect of slope aspect on RS and NRS microbial biomass and community composition has not been extensively studied. Knowledge of the influence of slope aspect on the differences between RS and NRS microbial communities could provide new insights into topographical influences of RE on local micro-ecosystem environments.

Soil microbial communities play important roles in soil quality and ecosystemic processes, including nutrient cycling, decomposition of organic matter, bioremediation of structural formation, and even plant interactions (Harris, 2009). These communities are closely associated with their surroundings, rapidly responding to changes and environmental stresses. Soil microbes are thus commonly used as sensitive indicators of change to soil quality under environmental stresses. Various microbial PLFAs represent the different nutritional requirements of the microbial groups. Bacteria and fungi form most of the microbial biomass and represent the main drivers of organic-matter turnover (Bååth and Anderson, 2003). Moreover, different kinds of bacteria produce different PLFAs: Gram-negative $\left(\mathrm{G}^{-}\right)$and Grampositive $\left(\mathrm{G}^{+}\right)$bacterial PLFA contents are usually considered indicators of chemolithotrophic and heterotrophic bacterial communities, respectively. $\mathrm{G}^{-}$bacteria are mainly associated with roots and thus decompose low-molecular-weight organic molecules (Griffiths et al., 1999), whereas $\mathrm{G}^{+}$bacteria decompose more complex materials, such as organic matter and litter (Kramer and Gleixner, 2006). Soil respiration is widely used for measuring microbial activity (e.g. basal respiration) or determining the potential microbial activity in soil (e.g. substrate-induced respiration) (Nannipieri et al., 1990; Wardle, 1995). These microbial indices are all sensitive bio-indicators that can be used to estimate soil quality and the effect of slope aspect on RS and NRS microbial communities. Soil ecologists have long been interested in the response of microbial communities to environmental factors for understanding the underlying mechanisms determining the content and composition of microbial biomass. Microbial communities have a close relationship with $\mathrm{pH}$, carbon (organic and water-soluble organic carbon), nitrogen (total nitrogen, ammonium and nitrate nitrogen, and water-soluble ammonium and nitrate nitrogen), and phosphorus (total and available phosphorus) (Bardelli et al., 2017; Huang et al., 2014; Nilsson et al., 2005; Ma et al., 2015). However, under the conditions of different slope aspects, the effect of the main soil nutrient factors on RS and NRS microbial communities on local micro-ecosystem environments remains unclear.

The Chinese government introduced the Grain for Green project in the 1990s to control soil erosion and improve the ecological environment of the Loess Plateau by converting large areas of sloping cropland to forest and grassland. Artemisia sacrorum - a perennial herb with multiple branches, well-developed root suckers, and high seed production and fertility - is widely distributed on the plateau (Wang and Liu, 2002), especially in the converted grassland. A. sacrorum was selected as a typical grassland plant of this region to study the effect of slope aspect on the MBC, total, fungal, bacterial, and actinomycete PLFA contents in RS and NRS and the differences in their REs. The main RS and NRS environmental factors affecting microbial content and composition were also identified. Three slope aspects (southfacing, north-facing, and northwest-facing slopes) with the same rehabilitation age were tested on the Loess Plateau in China. The following hypotheses were tested: (1) slope aspect significantly but differentially affects the MBC, total, fungal, bacterial, and actinomycete PLFA contents and their REs; and (2) soil carbon (C) and nitrogen (N) are the main soil nutrient factors that affect RS and NRS microbial communities under different slope aspects. 
Table 1. Characteristics of the sampling sites.

\begin{tabular}{lrrrl}
\hline $\begin{array}{l}\text { Slope } \\
\text { aspect }\end{array}$ & $\begin{array}{r}\text { Latitude } \\
\left({ }^{\circ} \mathrm{N}\right)\end{array}$ & $\begin{array}{r}\text { Longitude } \\
\left({ }^{\circ} \mathrm{E}\right)\end{array}$ & $\begin{array}{r}\text { Altitude } \\
(\mathrm{m})\end{array}$ & Plant community \\
\hline $\mathrm{S} 15^{\circ} \mathrm{W}$ & 36.85 & 109.31 & 1269 & A. sacrorum + Bothriochloa ischaemum \\
$\mathrm{N} 75^{\circ} \mathrm{W}$ & 36.85 & 109.31 & 1275 & A. sacrorum + Phragmites australis \\
$\mathrm{N} 57^{\circ} \mathrm{E}$ & 36.85 & 109.31 & 1278 & A. sacrorum + Artemisia capillaries \\
\hline
\end{tabular}

\section{Materials and methods}

\subsection{Study site}

A field experiment was conducted at the Ansai Research Station (ARS) of the Chinese Academy of Sciences $\left(36^{\circ} 51^{\prime} 30^{\prime \prime} \mathrm{N}, 109^{\circ} 19^{\prime} 23^{\prime \prime} \mathrm{E}\right.$; $1068-1309 \mathrm{~m}$ a.s.1.), northern Loess Plateau, China. The mean annual temperature of the study area is $8.8^{\circ} \mathrm{C}$, and the mean annual precipitation is approximately $505 \mathrm{~mm}$, with $>70 \%$ concentrated from July to September. Annual evaporation ranges from 1500 to $1800 \mathrm{~mm}$. To control soil erosion and improve the ecological environment, the Chinese government has implemented the policy of converting sloping cropland to grassland in the region in the 1990s. Synchronously, restoration of the local grassland is mainly dependent on abandoned farmland. In order to study the effect of slope aspect on the soil microbial community in the restored grassland, three grassland areas abandoned in the same year were selected for the experiment. The main vegetation in the region includes woods such as Robinia pseudoacacia and Platycladus orientalis; shrubs such as Caragana korshinskii, Hippophae rhamnoides, Syzygium aromaticum, and Ostryopsis davidiana; and herbage such as Artemisia sacrorum, Bothriochloa ischaemum, Setaria viridis, Artemisia giraldii, and Artemisia capillaris. Details of the soil properties and a map of sampling sites were described by Ai et al. (2017a).

\subsection{Experimental design and soil sampling}

The representative slopes of the three grassland areas were south-facing $\left(\mathrm{S} 15^{\circ} \mathrm{W}\right)$, northwest-facing $\left(\mathrm{N} 75^{\circ} \mathrm{W}\right)$, and north-facing $\left(\mathrm{N} 57^{\circ} \mathrm{E}\right)$, which had the same site conditions (all with Artemisia sacrorum as the dominant species, same rehabilitation age, geographical proximity) and represented sunny slope, half-sunny slope, and shady slope, respectively. The three study areas were selected in September 2014 after consultation with ARS researchers and reviewing relevant land documents. The basic characteristics are shown in Table 1.

Three replicate $10 \mathrm{~m} \times 10 \mathrm{~m}$ plots were established at each site (A. sacrorum was the dominant plant at each site). The distance between sampling plots within each sampling site was not less than $20 \mathrm{~m}$. Each plot was first surveyed for latitude, longitude, elevation, slope aspect, and slope gradient. Three $1 \mathrm{~m} \times 1 \mathrm{~m}$ quadrats were then randomly set in each plot to characterize the vegetation, e.g. plant species, coverage, and number. The plants were removed, and the soil strongly adhering to the roots, i.e. RS, was collected $(0-20 \mathrm{~cm}$ soil layer). Soil was also sampled from the same layer at locations approximately $15 \mathrm{~cm}$ from the plant roots (i.e. NRS). Each NRS sample was a composite of subsamples collected at five points (the four corners and the centre of the plot). A total of 18 soil samples ( 3 sites $\times 3$ plots per site $\times 2$ soil types) were collected, and each was divided into two subsamples: one subsample was placed in a cool container, and the other was placed into a cloth bag. The samples were then taken to the laboratory, and gravel and coarse fragments were removed. The container samples were homogenized and sieved to $2 \mathrm{~mm}$ and were also divided into two subsamples: one subsample was stored at $-80^{\circ} \mathrm{C}$, and the other was stored at $4{ }^{\circ} \mathrm{C}$ until analysis. The samples in the cloth bags were air-dried and sieved to 0.25 and $1 \mathrm{~mm}$ prior to analysis.

\subsection{Laboratory analysis}

The samples stored at $4{ }^{\circ} \mathrm{C}$ were used for determining MBC content $\left(\mathrm{mg} \mathrm{kg}^{-1}\right)$, basal respiration (BR; $\mathrm{mg} \mathrm{kg}^{-1} \mathrm{~h}^{-1}$ ), and substrate-induced respiration (SIR; $\mathrm{mg} \mathrm{kg}^{-1} \mathrm{~h}^{-1}$ ). Microbial biomass was measured by chloroform fumigation (Vance et al., 1987). The soil samples were fumigated for $24 \mathrm{~h}$ at $25.8^{\circ} \mathrm{C}$ with $\mathrm{CHCl}_{3}$ (ethanol free) after the fumigation or non-fumigation treatments and then were extracted with $100 \mathrm{~mL}$ of $0.5 \mathrm{M} \mathrm{K}_{2} \mathrm{SO}_{4}$ by horizontal shaking for $1 \mathrm{~h}$ at $200 \mathrm{rpm}$ and then filtered. The amount of $\mathrm{K}_{2} \mathrm{SO}_{4}$-extracted organic $\mathrm{C}$ was determined by a liquiTOCII analyser (Elementar, Hanau, Germany), and MBC content was calculated using a kEC (coefficient for extracting microbial carbon from the soil) factor of 0.38 (Vance et al., 1987). The soil BR was estimated by measuring the $\mathrm{CO}_{2}$ evolution from $10.0 \mathrm{~g}$ of field-fresh soils. The homogenized soil samples were first placed in a polyethylene bottle with rubber stopper (the soil water content was adjusted to $50 \%$ of field water-holding capacity). The polyethylene bottle was then incubated at $28^{\circ} \mathrm{C}$ for $2 \mathrm{~h}$, and the $\mathrm{CO}_{2}$ evolution was measured by an infrared gas analyser (QGS-08B, Beijing, China; Hueso et al., 2011). Soil SIR was determined using the same method as for BR but with the addition of $0.06 \mathrm{~g}$ glucose to the soil, after the glucose and soil were fully compounded, they were then incubated at $28^{\circ} \mathrm{C}$ for $1 \mathrm{~h}$.

The soil stored at $-80^{\circ} \mathrm{C}$ was used for the determination of PLFA contents. The structures of the microbial com- 
Table 2. Characterization of the microbial phospholipid fatty acids.

\begin{tabular}{|c|c|}
\hline Microbial group & Specific PLFA markers \\
\hline Gram-positive bacteria & $\begin{array}{l}\text { 11:0 anteiso, } 12: 0 \text { anteiso, } 13: 0 \text { iso, } 13: 0 \text { anteiso, } 14: 0 \text { iso, } 14: 0 \text { anteiso, } 15: 0 \text { iso, 15:0 } \\
\text { anteiso, } 15: 1 \text { iso w6c, 15:1 iso w9c, 16:0 iso, 16:0 anteiso, 17:0 iso, 17:0 anteiso, 18:0 } \\
\text { iso, 19:0 iso, 19:0 anteiso, 22:0 iso }\end{array}$ \\
\hline Gram-negative bacteria & $\begin{array}{l}\text { 12:1 w4c, } 12: 1 \text { w8c, } 14: 1 \text { w5c, } 14: 1 \text { w8c, } 14: 1 \text { w9c, } 15: 1 \text { w5 }, 15: 1 \text { w7c, } 15: 1 \text { w8c, } 16: 1 \\
\text { w7c DMA, } 16: 1 \text { w7c, } 16: 1 \text { w9c DMA, } 17: 0 \text { cyclo w7c, } 17: 1 \text { w5c, } 17: 1 \text { w7c, } 17: 1 \text { w8c, } \\
18: 1 \text { w5c, } 18: 1 \text { w6c, } 18: 1 \text { w7c, } 18: 1 \text { w8c, } 18: 1 \text { w9c, } 19: 0 \text { cyclo w6c, } 19: 0 \text { cyclo w7c, } \\
\text { 19:1 w6c, } 19: 1 \text { w8c, } 20: 1 \text { w6c, } 20: 1 \text { w9c, } 21: 1 \text { w } 3 c, 21: 1 \text { w5c, } 21: 1 \text { w6c, } 22: 1 \text { w3c, } 22: 1 \\
\text { w5c, } 22: 1 \text { w6c, } 22: 1 \text { w8c, } 22: 1 \text { w9c, } 24: 1 \text { w9c, } 19: 0 \text { cyclo } 9,10 \text { DMA }\end{array}$ \\
\hline Fungi & $16: 1 w 5 c, 18: 2 w 6 c$ \\
\hline Actinomycetes & $\begin{array}{l}\text { 16:0 10-methyl, 17:0 10-methyl, 17:1 w7c 10-methyl, 18:0 10-methyl, } 18: 1 \text { w7c 10- } \\
\text { methyl, 19:1 w7c 10-methyl, 20:0 10-methyl }\end{array}$ \\
\hline
\end{tabular}

munities were determined using a method (Bligh and Dyer, 1959) modified by Bardgett et al. (1996). Briefly, fatty acids were extracted from $3.0 \mathrm{~g}$ of freeze-dried soil using a solution containing citrate buffer, chloroform, and methanol. The PLFAs were separated from neutral and glycolipid fatty acids by solid-phase-extraction chromatography. After mild alkaline methanolysis, the PLFAs were analyzed using a gas chromatograph (GC7890A, Agilent Technologies Inc., Wilmington, USA) equipped with MIDI Sherlock software (version 4.5; MIDI Inc., Newark, USA).

An external standard of 19:0 methyl ester was used for quantification (Frostegård et al., 1993), and the amounts were expressed as nmol g${ }^{-1}$ for dry soil. Zelles (1999) reported that specific PLFA signatures could serve as indicators of specific microbial groups. Total PLFAs were obtained by summing the contents of all fatty acids detected in each sample. The classification of the PLFAs are shown in Table 2.

The concentrations of soil organic carbon (SOC), total nitrogen (TN), and total phosphorus at the sites have been reported by Ai et al. (2017a). Soil $\mathrm{pH}$ and available phosphorus (SAP), ammonium $\mathrm{N}\left(\mathrm{NH}_{4}\right)$, nitrate $\mathrm{N}\left(\mathrm{NO}_{3}\right)$, water-soluble organic $\mathrm{C}$ (WSOC), water-soluble $\mathrm{NH}_{4}\left(\mathrm{WNH}_{4}\right)$, and watersoluble $\mathrm{NO}_{3}\left(\mathrm{WNO}_{3}\right)$ contents were measured as described by Ai et al. (2017b). The soil moisture contents of sampling sites during the investigation were determined gravimetrically by drying the samples to a constant weight at $105^{\circ} \mathrm{C}$, and then the water content was expressed as a percentage of the soil dry weight. The characteristics of the rhizospheric and non-rhizospheric soils are shown in Table 3.

\subsection{Calculations and statistical analysis}

The metabolic quotient $\left(10^{3} \mathrm{~h}^{-1}\right)$ was calculated as BR per unit MBC: metabolic quotient $=10^{3} \times \mathrm{BR} / \mathrm{MBC}=10^{3} \times$ $\left(\mathrm{mg} \mathrm{kg}^{-1} \mathrm{~h}^{-1}\right) /\left(\mathrm{mg} \mathrm{kg}^{-1}\right)$ (Anderson and Domsch, 1993). $\mathrm{RE}$ was calculated as $\mathrm{RE}=\mathrm{Rs} / \mathrm{NRs}$, where Rs is a microbial property in RS, and NRs is a microbial property in NRS (Mukhopadhyay et al., 2016). For example, the RE for MBC:
$\mathrm{RE}=\mathrm{RS} \quad \mathrm{MBC} / \mathrm{NRS} \mathrm{MBC}=\left(\mathrm{mg} \mathrm{kg}^{-1}\right) /\left(\mathrm{mg} \mathrm{kg}^{-1}\right)$. All data were analyzed using one-way ANOVAs, followed by Duncan's tests at a probability level of $P<0.05$ for multiple comparisons. All statistical analyses were performed using SPSS 20.0 (SPSS Inc., Chicago, USA), and structural equation models were analyzed using the AMOS SPSS expansion pack. A redundancy analysis (RDA) was performed using CANOCO 5.0 (Biometris, Wageningen, the Netherlands). The graphs were plotted using SigmaPlot 12.5 (Systat Software, San Jose, USA).

\section{Results}

\subsection{Impacts of slope aspect on MBC content, respiration, and $\mathrm{BR} / \mathrm{MBC}$}

RS MBC content did not differ significantly among the slope aspects, but NRS MBC content in the north-facing slope was higher than those in the south- and northwest-facing slopes (Fig. 1a). The RE for MBC in the south-facing slope was highest among the slope aspects (Fig. 2a). Slope aspect did not affect BR, BR / MBC, or SIR in either RS or NRS (Fig. $1 \mathrm{~b}$ and Table 4). The RE for BR did not differ significantly among the slope aspects (Fig. 2a). The RE for SIR in the south-facing slope was higher than that in the northfacing slope.

\subsection{Impacts of slope aspect on microbial PLFA contents and composition}

The microbial PLFA contents in RS differed significantly among the slope aspects. Total PLFA contents in the northand northwest-facing slopes were $115 \%$ and $88 \%$ higher, respectively, than that in the south-facing slope (Fig. 3a). Fungal PLFA content did not differ significantly among the slope aspects (Fig. 3a). Bacterial PLFA content was similar to the trend for total PLFA content, with the lowest content in the 
Table 3. Characteristics of the rhizospheric and non-rhizospheric soils.

\begin{tabular}{llrrrrrrrrr}
\hline & Slope aspect & $\mathrm{pH}$ & $\begin{array}{r}\text { Water content } \\
(100 \%)\end{array}$ & $\begin{array}{r}\mathrm{SOC} \\
\left(\mathrm{g} \mathrm{kg}^{-1}\right)\end{array}$ & $\begin{array}{r}\mathrm{SAP} \\
\left(\mathrm{mg} \mathrm{kg}^{-1}\right)\end{array}$ & $\begin{array}{r}\mathrm{NO}_{3} \\
\left(\mathrm{mg} \mathrm{kg}^{-1}\right)\end{array}$ & $\begin{array}{r}\mathrm{NH}_{4} \\
\left(\mathrm{mg} \mathrm{kg}^{-1}\right)\end{array}$ & $\begin{array}{r}\mathrm{WSOC}_{\left(\mathrm{mg} \mathrm{kg}^{-1}\right)} \\
\left(\mathrm{mg} \mathrm{kg}^{-1}\right)\end{array}$ & $\begin{array}{r}\mathrm{WNO}_{3} \\
\left(\mathrm{mg} \mathrm{kg}^{-1}\right)\end{array}$ \\
\hline Rhizospheric soil & South-facing & 8.55 & 7.73 & 9.20 & 3.23 & 8.60 & 12.94 & 59.12 & 1.55 \\
& North-facing & 8.72 & 10.37 & 7.36 & 2.41 & 9.70 & 9.87 & 37.02 & 1.27 & 0.61 \\
& Northwest-facing & 8.63 & 10.60 & 5.21 & 1.98 & 7.33 & 9.05 & 45.32 & 1.77 & 0.44 \\
\hline Non-rhizospheric & South-facing & 8.54 & 8.13 & 5.53 & 1.35 & 4.93 & 12.32 & 38.14 & 1.20 \\
& North-facing & 8.58 & 10.31 & 4.90 & 1.37 & 6.73 & 13.13 & 36.47 & 0.98 \\
& Northwest-facing & 8.58 & 10.45 & 4.27 & 1.68 & 6.27 & 12.42 & 40.39 & 1.38 & 0.38 \\
& & & &
\end{tabular}

SOC: soil organic carbon, $\mathrm{SAP}$ : available phosphorus, $\mathrm{NO}_{3}$ : nitrate nitrogen, $\mathrm{NH}_{4}$ : ammonium nitrogen, WSOC: water-soluble organic carbon, $\mathrm{WNO}$ : water-soluble nitrate nitrogen, $\mathrm{WNH}_{4}$ : water-soluble ammonium nitrogen. The above data are average values $(n=3)$.

Table 4. Microbial respiratory quotients (BR / MBC), ratios of fungal PLFA content to bacteria PLFA content $(F / B)$, and ratios of $\mathrm{G}^{+}$PLFA content to $\mathrm{G}^{-}$PLFA content $\left(\mathrm{G}^{+} / \mathrm{G}^{-}\right)$in the rhizospheric and non-rhizospheric soils. Values are means \pm standard errors $(n=3)$.

\begin{tabular}{|c|c|c|c|c|c|c|}
\hline \multirow[t]{2}{*}{ Slope aspect } & \multicolumn{3}{|c|}{ Rhizospheric soil } & \multicolumn{3}{|c|}{ Non-rhizospheric soil } \\
\hline & $\mathrm{BR} / \mathrm{MBC}\left(10^{3} \mathrm{~h}^{-1}\right)$ & $F / B$ ratio & $\mathrm{G}^{+} / \mathrm{G}^{-}$ratio & $\mathrm{BR} / \mathrm{MBC}\left(10^{3} \mathrm{~h}^{-1}\right)$ & $F / B$ ratio & $\mathrm{G}^{+} / \mathrm{G}^{-}$ratio \\
\hline South-facing & $3.03 \pm 0.49 a$ & $0.07 \pm 0.00 a$ & $2.16 \pm 0.58 a$ & $2.47 \pm 0.52 a$ & $0.07 \pm 0.00 a$ & $1.45 \pm 0.23 a$ \\
\hline Northwest-facing & $2.77 \pm 0.23 a$ & $0.04 \pm 0.00 b$ & $1.54 \pm 0.16 a$ & $2.47 \pm 0.35 a$ & $0.05 \pm 0.00 a b$ & $1.33 \pm 0.06 a$ \\
\hline
\end{tabular}

Different lowercase letters in the same column indicate significant differences at $P=0.05$.

south-facing slope (Fig. 3b). In contrast to total PLFA content, the ratio of fungal PLFA content to bacterial PLFA content $(F / B$ ratio $)$ in the south-facing slope was significantly higher than those in the north- and northwest-facing slopes (Table 4). Both $\mathrm{G}^{+}$and $\mathrm{G}^{-}$PLFA contents had trends similar to that of the bacterial PLFA content, with the lowest contents in the south-facing slope (Fig. 3b). The ratio of $\mathrm{G}^{+}$ PLFA content to $\mathrm{G}^{-}$PLFA content $\left(\mathrm{G}^{+} / \mathrm{G}^{-}\right.$ratio) did not differ significantly among the slope aspects (Table 4). Actinomycete PLFA content in the north-facing slope was $102 \%$ higher than that in the south-facing slope, similar to that of $\mathrm{G}^{-}$PLFA content (Fig. 3a).

The composition of the NRS PLFA contents also differed significantly among the slope aspects. Total PLFA content in the north-facing slope was $50 \%$ and $62 \%$ higher than those in the south- and northwest-facing slopes, respectively (Fig. 3c). Bacterial PLFA content had a trend similar to that of total PLFA content, with the highest content in the northfacing slope (Fig. 3d). Fungal PLFA content in the southand north-facing slopes was significantly higher than that in the northwest-facing slope (Fig. 3c). The $F / B$ ratio in the south-facing was substantially higher than that in the northfacing slope (Table 4). $\mathrm{G}^{-}$PLFA content had a trend similar to that of bacterial PLFA content, and $\mathrm{G}^{+}$PLFA content did not differ significantly among the slope aspects (Fig. 3d). The $\mathrm{G}^{+} / \mathrm{G}^{-}$ratio did not differ significantly among the slope aspects (Table 4). Actinomycete PLFA content had a trend similar to that of fungal PLFA content, with higher contents in the south- and north-facing slopes, which were $149 \%$ and
$117 \%$ higher, respectively, than that in the northwest-facing slope (Fig. 3d).

The REs for total, bacterial, $\mathrm{G}^{+}, \mathrm{G}^{-}$, and actinomycete PLFA contents differed significantly among the slope aspects, but the RE for fungal PLFA content did not (Fig. 2b and c). The REs for total, $\mathrm{G}^{+}, \mathrm{G}^{-}$, bacterial, and actinomycete PLFA contents in the northwest-facing slope were highest among the slope aspects.

\subsection{Redundancy analysis (RDA)}

The constrained RDAs indicated that environmental factors affected RS microbial characteristics (Fig. 4a). The total variation was 6.10 , and the explanatory variables accounted for $96.8 \%$. The first two axes (RDA1 and RDA2) explained $89.6 \%$ of the total variance, wherein $84.1 \%$ was attributed to RDA1 and $5.5 \%$ to RDA2. WSOC content was the most significant of the seven environmental factors and explained $63.6 \%(P=0.006)$ of the total variance. The slope aspect was the next most significant environmental variable and explained $62.8 \%(P=0.004)$, followed by $\mathrm{NH}_{4}(58.6 \%$, $P=0.004)$, SAP $(45.7 \%, P=0.022)$, and $\mathrm{WNH}_{4}(45.2 \%$, $P=0.032)$ contents.

The constrained RDAs indicated that environmental factors affected NRS microbial characteristics (Fig. 4b). The total variation was 2.97 , and the explanatory variables accounted for $94.2 \%$. RDA1 and RDA2 explained $81.6 \%$ of the total variance, $68.3 \%$ for RDA1 and $13.3 \%$ for RDA2. Among the seven environmental factors, $\mathrm{WNO}_{3}$ content was 

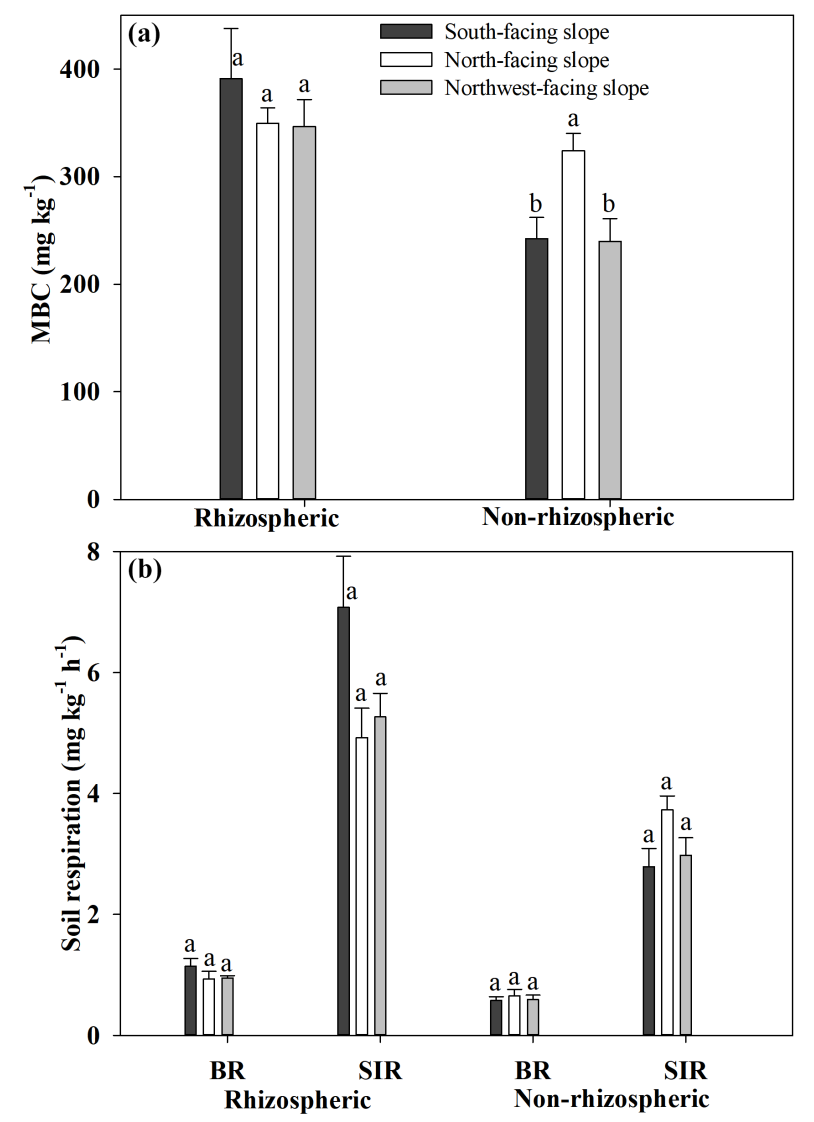

Figure 1. Microbial biomass carbon (MBC) content, basal respiration (BR), and substrate-induced respiration (SIR) in the rhizospheric and non-rhizospheric soils. Error bars are standard errors $(n=3)$. Different letters above the bars indicate significant differences at $P=0.05$.

the most significant and explained $34.7 \%(P=0.04)$ of the total variance.

\subsection{Path analysis}

The final structural equation model based on all indices adequately fitted the data to describe the effects of the environmental factors on RS microbial characteristics $\left(x^{2}=0.506\right.$; $P=0.918$; RMSEA, $P<0.001$; Fig. 5a). The final model accounted for $99 \%$ of the variation in RS WSOC content, with $71 \%$ of the variation in bacterial PLFA content, $78 \%$ of the variation in $\mathrm{G}^{+}$PLFA content, and $72 \%$ of the variation in total PLFA content. Slope aspect was positively correlated with WSOC content $(P<0.001)$. WSOC content was negatively correlated with bacterial PLFA $(P<0.001), \mathrm{G}^{+}$PLFA $(P<0.001)$, and total PLFA $(P<0.001)$ contents.

All indices adequately fitted the data to describe the effects of the environmental factors on NRS microbial characteristics $\left(x^{2}=3.222 ; P=0.521\right.$; RMSEA, $P<0.001$; Fig. $\left.5 b\right)$. The model was able to explain $59 \%$ of the variation in $\mathrm{WNH}_{4}$ content, $58 \%$ of the variation in MBC content, $55 \%$
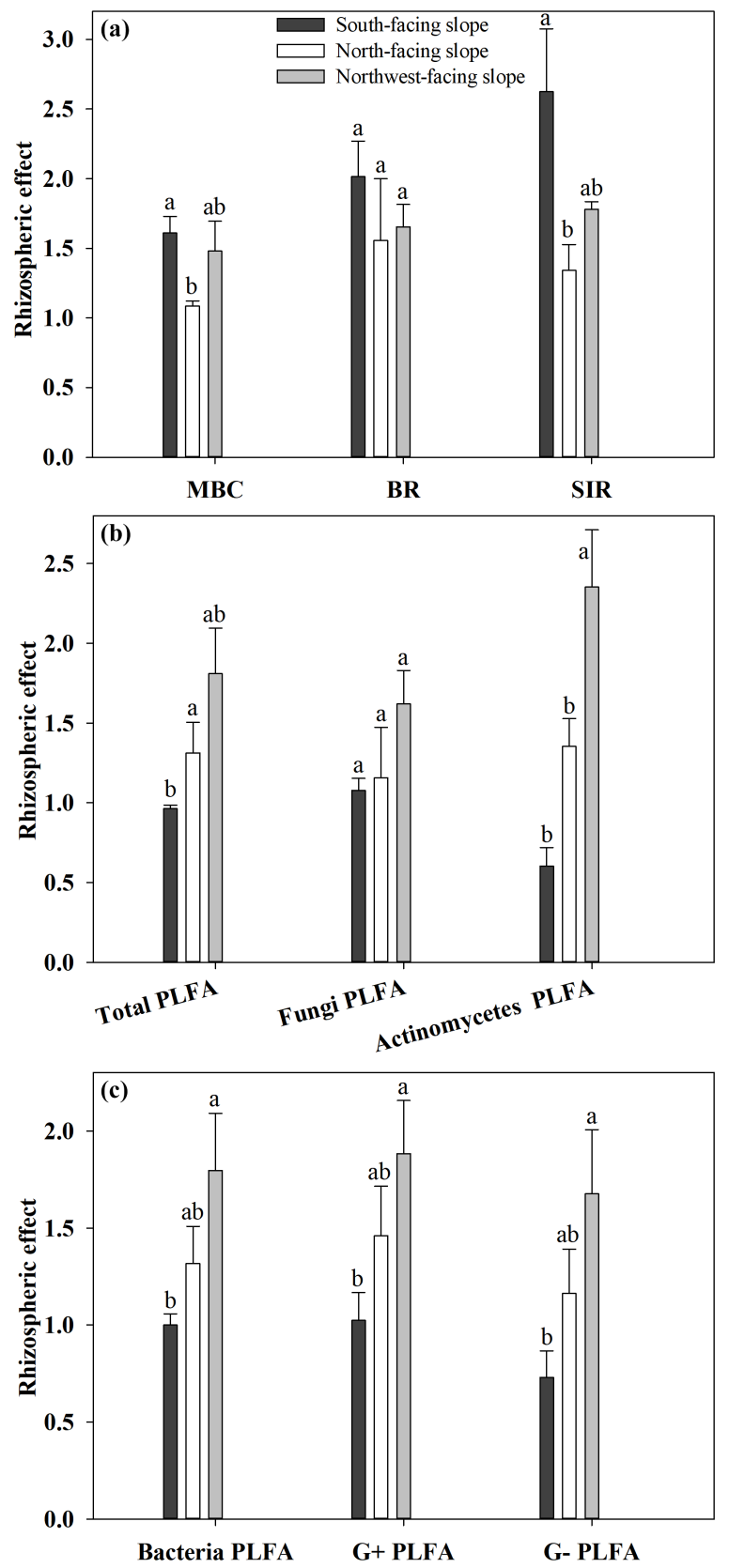

Figure 2. The rhizospheric effects of MBC, BR, SIR, and PLFA contents. Error bars are standard errors $(n=3)$. Different letters above the bars indicate significant differences at $P=0.05$.

of the variation in $\mathrm{G}^{-}$PLFA content, and $45 \%$ of variation in total PLFA content. Slope aspect was strongly positively correlated with $\mathrm{WNH}_{4}$ content $(P<0.001)$. $\mathrm{WNH}_{4}$ content was strongly negatively correlated with MBC $(P<0.001)$, $\mathrm{G}^{-}$PLFA $(P<0.05)$, and total PLFA $(P<0.05)$ contents. 

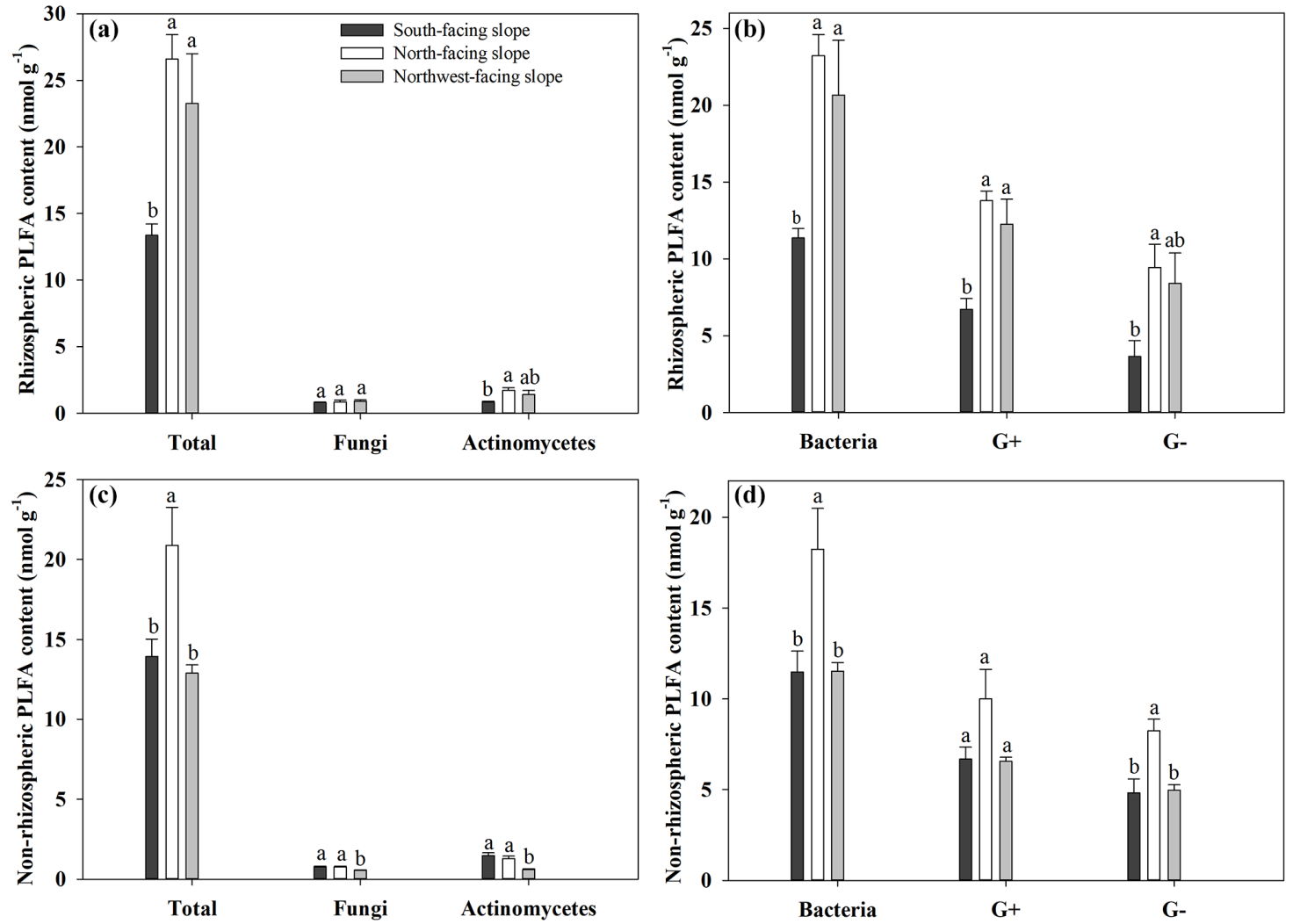

Figure 3. Effects of slope aspect on PLFA contents in rhizospheric and non-rhizospheric soils. Error bars are standard errors $(n=3)$. Different letters above the bars indicate significant differences at $P=0.05$.

\section{Discussion}

\subsection{MBC, respiration, and BR / MBC}

Soil microbial biomass is closely associated with soilmoisture content (Zhang et al., 2005; Drenovsky et al., 2010; Ma et al., 2015). The north-facing slope contained more moisture than the south-facing slope (Sariyildiz et al., 2005), so microbial activity in the north-facing slope was higher than that in the south-facing slope. NRS MBC content in the north-facing slope was significantly higher than that in the south-facing slope in our study, supporting our hypothesis 1 and in agreement with other studies (Huang et al., 2015; Sidari et al., 2008). Carletti et al. (2009), however, reported an opposite trend: soil MBC content was higher in a south-facing slope. This disparity may have been due to the differences in plant species, soil type, and regional climate (Gilliam et al., 2014). NRS MBC content in the northwestfacing slope was lower than that in the north-facing slope, inconsistent with Huang et al. (2015), whose study area had the same soil and climatic conditions as ours. The different result may mainly be due to the different plant species: the effect of shrubland plants (Huang et al., 2015) on NRS may be different from the effect of grassland plants (our study). Plant shade can affect soil microbial activity (Blok et al., 2010), so different shading can lead to different MBC contents.

Plant roots release a high amount of exudates, such as sugars, amino acids, organic acids, hormones, and enzymes (Zhang et al., 2012; Grayston et al., 1997). In contrast, soil with a low amount of shading is prone to desiccation (Wang et al., 2008), and the quantity of exudates released by plant roots is low, which may lead to lower activities of the microorganisms. RS MBC content therefore should be higher than NRS MBC content, consistent with our results. In our study, the RE for MBC content in the south-facing slope was significantly higher than that in the north-facing slope. The light in south-facing slopes would have a greater impact on the soil micro-environment than that in north-facing slopes, because south-facing slopes in the Northern Hemisphere receive more sunlight than north-facing slopes, leading to a larger difference between RS and NRS in southfacing slopes. The RDA and path analysis found that NRS WSOC, $\mathrm{WNO}_{3}$, and $\mathrm{WNH}_{4}$ contents were well correlated with MBC content (Figs. 4b and 5b), supporting our hypothesis that soil $\mathrm{C}$ and $\mathrm{N}$ are the main soil nutrient factors that affect RS and NRS microbial communities, and in agreement with other studies (Haynes, 2000; Huang et al., 2014). 

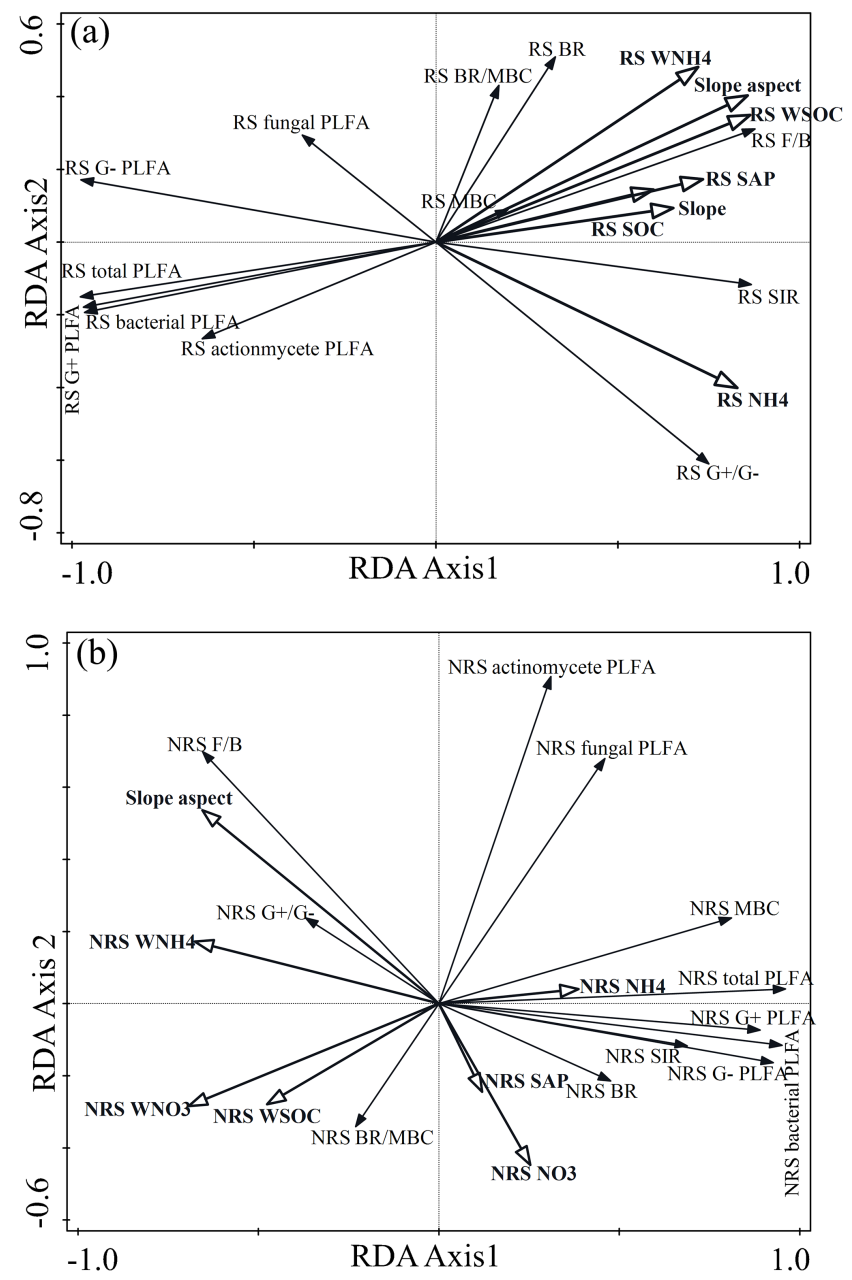

Figure 4. Bidimensional graph for a redundancy analysis (RDA) of the relationships between microbial properties and environmental factors in the rhizospheric (a) and non-rhizospheric (b) soils. Note: RS, rhizospheric soil; NRS, non-rhizospheric soil; MBC, microbial biomass carbon; BR, basal respiration; SIR, substrateinduced respiration; $F / B$, the ratio of fungal PLFA content to bacterial PLFA content; $\mathrm{G}^{+} / \mathrm{G}^{-}$, the ratio of $\mathrm{G}^{+}$PLFA content to $\mathrm{G}^{-}$PLFA content; SAP, available phosphorus; SOC, soil organic carbon; $\mathrm{NH}_{4}$, ammonium nitrogen; $\mathrm{NO}_{3}$, nitrate nitrogen; WSOC, water-soluble organic carbon; $\mathrm{WNH}_{4}$, water-soluble ammonium nitrogen; $\mathrm{WNO}_{3}$, water-soluble nitrate nitrogen.

Neither RS nor NRS BR, SIR, and BR / MBC differed significantly among the slope aspects, indicating that the actual microbial activities, potential microbial activities, and bioenergetic status of the microbial biomass (Nannipieri et al., 1990; Wardle, 1995; Sinha et al., 2009) were similar among the slope aspects in the study area. The RE of SIR in the south-facing slope was $96 \%$ higher than that in the northfacing slope, indicating that the effect of slope aspect on the RS and NRS SIRs was more evident in the south-facing slope than that in the north-facing slope, even though the influence

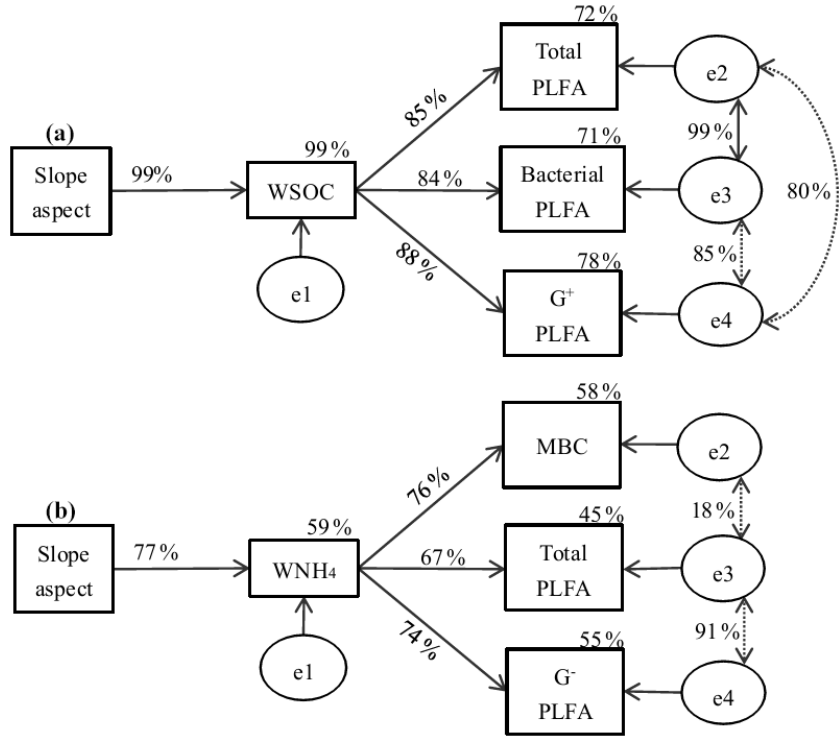

Figure 5. Structural equation models of the effect of slope aspect on microbial properties in the rhizospheric (a) and nonrhizospheric (b) soils. Numbers beside the arrows are standardized path coefficients (equivalent to correlation coefficients). Solid lines indicate significant standardized path coefficients $(P<0.05)$. Circles indicate error terms (e1-e4). Percentages near the endogenous variables indicate the variance explained by the model.

of slope aspect on SIR was not significant either in RS or NRS.

\subsection{PLFA contents and composition}

\subsubsection{Fungal and bacterial PLFA contents and composition}

NRS fungal PLFA content in the northwest-facing slope was lower than those in the south- and north-facing slopes, but RS fungal PLFA content did not differ significantly among the slope aspects. Previous studies have reported different results: Huang et al. (2015) and Gilliam et al. (2014) found that slope aspect significantly affected the fungal community, and fungal abundance was lower in north-facing slope; Bardelli et al. (2017) found that fungal abundance did not differ significantly between north- and south-facing slopes. These different results may be due to the differences in plant species (e.g. herbs vs. shrubs), soil conditions, climate, and research methods (Gilliam et al., 2014). The different responses of RS and NRS fungal PLFA contents indicated that rhizospheres could form an environment that negates the effect of slope aspect on fungal communities more than non-rhizospheric zones. SOC and TN can supply the microbial biomass with enough $\mathrm{C}, \mathrm{N}$, and energy resources to support microbial growth (Jia et al., 2005), so the solubility of SOC (WSOC) and nitrogen $\left(\mathrm{WNO}_{3}, \mathrm{WNH}_{4}\right)$ would be closely associated with the fungal community. The RDA found that NRS WSOC and $\mathrm{WNO}_{3}$ 
were well correlated with fungal PLFA content (Fig. 4b), supporting our hypothesis 2 and agreeing with previous studies (Haynes, 2000; Nilsson et al., 2005; Huang et al., 2014).

The effect of slope aspect on PLFA content differed between bacteria and fungi. Both RS and NRS bacterial PLFA contents in the south-facing slope were lower than those in the north-facing slope, suggesting more soil moisture in the north-facing slope suitable for the growth of bacteria, in agreement with some studies (Huang et al., 2015; Ascher et al., 2012) but not others (Gilliam et al., 2014; Bardelli et al., 2017). The effect of slope aspect on the bacterial community would therefore become significant due to the plant species, soil type, and climatic conditions. The RE for bacterial PLFA content in the northwest-facing slope was significantly higher than that in the south-facing slope, indicating that the environmental conditions of the rhizosphere helped the bacterial community to resist environmental pressure. The RDA indicated that the RS $\mathrm{WNH}_{4}$, WSOC, and SAP contents were well correlated with the bacterial PLFA content, and the NRS $\mathrm{WNH}_{4}$ content was well correlated with the bacterial PLFA content (Fig. 4a, b). The path analysis indicated that RS WSOC content was the main factor influencing the bacterial PLFA content and mainly affected the $\mathrm{G}^{+}$PLFA content (Fig. 5a), in agreement with another study (Fierer et al., 2003), but the NRS $\mathrm{WNH}_{4}$ content mainly affected the $\mathrm{G}^{-}$PLFA content (Fig. 5b). These results indicated that the RS and NRS bacterial PLFA contents were affected by different soil nutrient factors.

Soil moisture is an important environmental factor affecting the composition of microbial communities, the higher amounts of soil moisture in north-facing slopes (Sariyildiz et al., 2005) can lead to lower $F / B$ ratios (Brockett et al., 2012; Drenovsky et al., 2010; Ma et al., 2015). The $F / B$ ratio in our study was highest in the south-facing slope and lowest in the north-facing slope for both RS and NRS, consistent with previous studies (Huang et al., 2015; Gilliam et al., 2014). The higher amount of soil moisture in the northfacing slope would reduce soil aeration, and lower oxygen levels would create an environment favourable for facultative and obligate anaerobic bacteria (Drenovsky et al., 2004). Drought stress in the south-facing slope would likely facilitate the survival of fungi, because soil fungi rely on more aerobic conditions and are more tolerant of drought due to their filamentous nature (Zhang et al., 2005). The significant difference in the RE for bacterial PLFA content was not obvious for fungal PLFA content, so the RE was much weaker in the fungal than the bacterial community, consistent with Buyer et al. (2002). These results indicated that RE had a large effect on the structures of the fungal and bacterial communities.

Previous studies have found that wetter soils are more enriched in $\mathrm{G}^{+}$bacteria (Zhang et al., 2005; Drenovsky et al., 2010; Ma et al., 2015), in agreement with the result of the RE $\mathrm{G}^{+}$PLFA content, but not the NRE $\mathrm{G}^{+}$PLFA content. As RE was significantly affected by slope aspect for the $\mathrm{G}^{+}$PLFA content, this may be one of the reasons that caused the difference between RE and NRE G ${ }^{+}$PLFA contents. Furthermore, the RDA indicated that the RS WSOC was well correlated

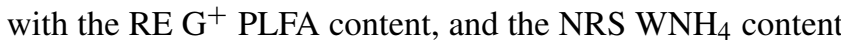
was well correlated with the NRE G ${ }^{+}$PLFA content (Fig. 4a, b). Although drier soils tend to be more enriched in $\mathrm{G}^{-}$bacteria (Zhang et al., 2005; Drenovsky et al., 2010; Ma et al., 2015), both the higher RE and NRE G ${ }^{-}$PLFA contents were recorded at the north-facing slope. It has been shown that drier soils can lead to low root exudates, which may lead to lower activities of the soil microorganisms (Zhang et al., 2015). The $\mathrm{G}^{+} / \mathrm{G}^{-}$ratio can indicate the dominance of bacteria in soil microbial communities (Tscherko et al., 2004; Zhang et al., 2015). Neither the RS nor the NRS G ${ }^{+} / \mathrm{G}^{-}$ratio was affected by slope aspect, indicating that slope aspect did not significantly affect the dominant bacterial community in either RS or NRS.

\subsubsection{Actinomycete and total PLFA contents}

RS and NRS actinomycete PLFA contents were significantly affected by slope aspect, supporting our hypothesis 1 . Actinomycetes and $\mathrm{G}^{+}$bacteria have similar life habits, so wetter soils are more enriched in actinomycetes (Zhang et al., 2005; Drenovsky et al., 2010; Ma et al., 2015). RS actinomycete PLFA content in the north-facing slope was therefore higher than that in the south-facing slope, and the northwest-facing slope had more moderate growth conditions for actinomycetes compared with the north-facing and south-facing slopes. NRS actinomycete PLFA content, however, was lower in the northwest-facing slope than those in the north-facing and south-facing slopes. This difference may have been due to RE, because RE in the northwestfacing slope was significantly higher than those in the other slopes. RE will affect soil nutrients more in RS than NRS (Zhang et al., 2012; Grayston et al., 1997). The RDA indicated that the RS but not NRS actinomycete PLFA content was well correlated with WSOC and $\mathrm{WNH}_{4}$ contents, supporting our hypothesis 2 (Fig. 4a, b).

The $\mathrm{G}^{+}$and actinomycete PLFA contents accounted for more than $50 \%$ of total PLFA content in both RS $(57 \%$ $59 \%)$ and NRS (54\%-58\%), so the distribution of total PLFA content in our study area depended mainly on the $\mathrm{G}^{+}$and actinomycete PLFA contents. Wetter soils tend to be more enriched in $\mathrm{G}^{+}$bacteria and actinomycetes (Zhang et al., 2005; Drenovsky et al., 2010; Ma et al., 2015), so total PLFA contents in both RS and NRS were highest in the north-facing slope. Total PLFA content, however, was higher in the northwest-facing slope than that in the southfacing slope for RS and did not differ significantly between the northwest-facing and south-facing slopes in NRS. These differences in total PLFA content between RS and NRS may have been mostly due to RE. The shading by herbs in the northwest-facing slope may make RS as suitable for microbial life as in the north-facing slope, whereas NRS in the 
northwest-facing slope was not suitable for microbial life as in the south-facing slope without plant shading. The path analysis indicated that WSOC content had a significant effect on RS total PLFA content and that $\mathrm{WNH}_{4}$ content had a significant effect on NRS total PLFA content (Fig. 5a, b), as expected (Haynes, 2000; Huang et al., 2014; Nilsson et al., 2005). These results supported our hypotheses 1 and 2 , but hypothesis 1 was inconsistent with the study by Huang et al. (2015) who found a significantly higher total PLFA content in a south-facing slope than in other slopes. RE may have been one of the main reasons, because shrub shading (Huang et al., 2015) clearly differs from herb shading (our study), which could be caused by a different RE (Blok et al., 2010).

\section{Conclusions}

This study provides experimental evidence that slope aspect can markedly but differentially affect MBC and PLFA contents in RS and NRS that and the different influences can produce an evident RE; the RE for most microbial properties was higher in the northwest-facing slope. WSOC content was well correlated with RS microbial properties, and $\mathrm{WNH}_{4}$ content was well correlated with NRS microbial properties, likely due to RE. Studies of the influence of slope aspect on soil microbial communities should therefore consider REs. This study provides new insights into the influences of topographic factors affecting the mechanisms driving the structure of microbial communities in a micro-ecosystem environment. Further field investigation on different plant species, however, is needed to determine the role of RE under the effect of slope aspect in micro-ecosystem environments.

Data availability. The underlying research data in this study are available from the first author on request (aizmxs@yeah.net).

Author contributions. GBL and SX provided research ideas and designed the experiments. They were also responsible for the revision of the paper. SX, ZMA, JYZ, and HFL participated in the collection of soil samples, and ZMA, JYZ, and HFL contributed to the soil analysis. ZMA analyzed the data and wrote the paper.

Competing interests. The authors declare that they have no conflict of interest.

Acknowledgements. We thank the National Natural Science Foundation of China $(41771557,41471438)$, the Science and Technology Basic Work of the Science and Technology Ministry of China (2014FY210100) and the West Young Scholars Project of the Chinese Academy of Sciences (XAB2015A05) for funding this work.
Edited by: Elias Samankassou

Reviewed by: three anonymous referees

\section{References}

Ai, Z. M., He, L. R., Xin, Q., Yang, T., Liu, G. B., and Xue, S.: Slope aspect affects the non-structural carbohydrates and $\mathrm{C}: \mathrm{N}: \mathrm{P}$ stoichiometry of Artemisia sacrorum on the Loess Plateau in China, Catena, 152, 9-17, https://doi.org/10.1016/j.catena.2016.12.024, 2017a.

Ai, Z. M., Zhang, J. Y., Liu, H. F., Xin, Q., Xue, S., and Liu, G. B.: Soil nutrients influence the photosynthesis and biomass in invasive Panicum virgatum on the Loess Plateau in China, Plant Soil, 418, 153-164, https://doi.org/10.1007/s11104-017-3286-x, $2017 b$.

Anderson, T.-H. and Domsch, K.: The metabolic quotient for $\mathrm{CO}_{2}\left(\mathrm{qCO}_{2}\right)$ as a specific activity parameter to assess the effects of environmental conditions, such as $\mathrm{pH}$, on the microbial biomass of forest soils, Soil Biol. Biochem., 25, 393-395, https://doi.org/10.1016/0038-0717(93)90140-7, 1993.

Ascher, J., Sartori, G., Graefe, U., Thornton, B., Ceccherini, M., Pietramellara, G., and Egli, M.: Are humus forms, mesofauna and microflora in subalpine forest soils sensitive to thermal conditions?, Biol. Fert. Soils, 48, 709-725, https://doi.org/10.1007/s00374-012-0670-9, 2012.

Bååth, E. and Anderson, T.-H.: Comparison of soil fungal/bacterial ratios in a $\mathrm{pH}$ gradient using physiological and PLFA-based techniques, Soil Biol. Biochem., 35, 955-963, https://doi.org/10.1016/S0038-0717(03)00154-8, 2003.

Bardelli, T., Gómez-Brandón, M., Ascher-Jenull, J., Fornasier, F., Arfaioli, P., Francioli, D., Egli, M., Sartori, G., Insam, H., and Pietramellara, G.: Effects of slope exposure on soil physicochemical and microbiological properties along an altitudinal climosequence in the Italian Alps, Sci. Total Environ., 575, 1041-1055, https://doi.org/10.1016/j.scitotenv.2016.09.176, 2017.

Bardgett, R. D., Hobbs, P. J., and Frostegård, Å.: Changes in soil fungal: bacterial biomass ratios following reductions in the intensity of management of an upland grassland, Biol. Fert. Soils, 22, 261-264, https://doi.org/10.1007/BF00382522, 1996.

Bennie, J., Huntley, B., Wiltshire, A., Hill, M. O., and Baxter, R.: Slope, aspect and climate: Spatially explicit and implicit models of topographic microclimate in chalk grassland, Ecol. Model., 216, 47-59, https://doi.org/10.1016/j.ecolmodel.2008.04.010, 2008.

Bligh, E. G. and Dyer, W. J.: A rapid method of total lipid extraction and purification, Can. J. Biochem. Phys., 37, 911-917, https://doi.org/10.1139/y59-099, 1959.

Blok, D., Heijmans, M. M., Schaepmanstrub, G., Kononov, A., Maximov, T., and Berendse, F.: Shrub expansion may reduce summer permafrost thaw in Siberian tundra, Global Change Biol., 16, 1296-1305, https://doi.org/10.1111/j.13652486.2009.02110.x, 2010.

Brockett, B. F. T., Prescott, C. E., and Grayston, S. J.: Soil moisture is the major factor influencing microbial community structure and enzyme activities across seven biogeoclimatic zones in western Canada, Soil Biol. Biochem., 44, 9-20, https://doi.org/10.1016/j.soilbio.2011.09.003, 2012. 
Buyer, J. S., Roberts, D. P., and Russek-Cohen, E.: Soil and plant effects on microbial community structure, Can. J. Microbiol., 48, 955-964, https://doi.org/10.1139/W02-095, 2002.

Carletti, P., Vendramin, E., Pizzeghello, D., Concheri, G., Zanella, A., Nardi, S., and Squartini, A.: Soil humic compounds and microbial communities in six spruce forests as function of parent material, slope aspect and stand age, Plant Soil, 315, 47-65, https://doi.org/10.1007/s11104-008-9732-z, 2009.

Chen, C., Condron, L., Davis, M., and Sherlock, R.: Phosphorus dynamics in the rhizosphere of perennial ryegrass (Lolium perenne L.) and radiata pine (Pinus radiata D. Don.), Soil Biol. Biochem., 34, 487-499, https://doi.org/10.1016/S0038-0717(01)00207-3, 2002.

Dearborn, K. D. and Danby, R. K.: Aspect and slope influence plant community composition more than elevation across foresttundra ecotones in subarctic Canada, J. Veg. Sci., 28, 595-604, https://doi.org/10.1111/jvs.12521, 2017.

Drenovsky, R., Vo, D., Graham, K., and Scow, K.: Soil water content and organic carbon availability are major determinants of soil microbial community composition, Microb. Ecol., 48, 424430, https://doi.org/10.1007/s00248-003-1063-2, 2004.

Drenovsky, R. E., Steenwerth, K. L., Jackson, L. E., and Scow, K. M.: Land use and climatic factors structure regional patterns in soil microbial communities, Global Ecol. Biogeogr., 19, 27-39, https://doi.org/10.1111/j.1466-8238.2009.00486.x, 2010.

Fierer, N., Schimel, J. P., and Holden, P. A.: Variations in microbial community composition through two soil depth profiles, Soil Biol. Biochem., 35, 167-176, https://doi.org/10.1016/S00380717(02)00251-1, 2003.

Frostegård, A., Tunlid, A., and Bååth, E.: Phospholipid fatty acid composition, biomass, and activity of microbial communities from two soil types experimentally exposed to different heavy metals, Appl. Environ. Microbiol., vol. 59, available at: https: //aem.asm.org/content/59/11/3605 (last access: 8 October 2018), 1993.

Gilliam, F. S., Hédl, R., Chudomelová, M., McCulley, R. L., and Nelson, J. A.: Variation in vegetation and microbial linkages with slope aspect in a montane temperate hardwood forest, Ecosphere, 5, 1-17, https://doi.org/10.1890/ES13-00379.1, 2014.

Grayston, S., Vaughan, D., and Jones, D.: Rhizosphere carbon flow in trees, in comparison with annual plants: the importance of root exudation and its impact on microbial activity and nutrient availability, Appl. Soil Ecol., 5, 29-56, https://doi.org/10.1016/S0929-1393(96)00126-6, 1997.

Griffiths, B. S., Bonkowski, M., Dobson, G., and Caul, S.: Changes in soil microbial community structure in the presence of microbial-feeding nematodes and protozoa, Pedobiologia, 43, 297-304, 1999.

Harris, J.: Soil microbial communities and restoration ecology: facilitators or followers?, Science, 325, 573-574, https://doi.org/10.1126/science.1172975, 2009.

Haynes, R.: Labile organic matter as an indicator of organic matter quality in arable and pastoral soils in New Zealand, Soil Biol. Biochem., 32, 211-219, https://doi.org/10.1016/S00380717(99)00148-0, 2000

Hinsinger, P., Bengough, A. G., Vetterlein, D., and Young, I. M.: Rhizosphere: biophysics, biogeochemistry and ecological relevance, Plant Soil, 321, 117-152, https://doi.org/10.1007/s11104008-9885-9, 2009.
Huang, X., Liu, S., Wang, H., Hu, Z., Li, Z., and You, Y.: Changes of soil microbial biomass carbon and community composition through mixing nitrogen-fixing species with Eucalyptus urophylla in subtropical China, Soil Biol. Biochem., 73, 42-48, https://doi.org/10.1016/j.soilbio.2014.01.021, 2014.

Huang, Y.-M., Liu, D., and An, S.-S.: Effects of slope aspect on soil nitrogen and microbial properties in the Chinese Loess region, Catena, 125, 135-145, https://doi.org/10.1016/j.catena.2014.09.010, 2015.

Hueso, S., Hernández, T., and García, C.: Resistance and resilience of the soil microbial biomass to severe drought in semiarid soils: The importance of organic amendments, Appl. Soil Ecol., 50, 27-36, https://doi.org/10.1016/j.apsoil.2011.07.014, 2011.

Jia, G. M., Cao, J., Wang, C. Y., and Wang, G.: Microbial biomass and nutrients in soil at the different stages of secondary forest succession in Ziwulin, northwest China, Forest. Ecol. Manag., 217, 117-125, https://doi.org/10.1016/j.foreco.2005.05.055, 2005.

Kramer, C. and Gleixner, G.: Variable use of plantand soil-derived carbon by microorganisms in agricultural soils, Soil Biol. Biochem., 38, 3267-3278, https://doi.org/10.1016/j.soilbio.2006.04.006, 2006.

Liu, M., Zheng, R., Bai, S., and Wang, J.: Slope aspect influences arbuscular mycorrhizal fungus communities in arid ecosystems of the Daqingshan Mountains, Inner Mongolia, North China, Mycorrhiza, 27, 189-200, https://doi.org/10.1007/s00572-016-07397, 2017

Ma, L., Guo, C., Lü, X., Yuan, S., and Wang, R.: Soil moisture and land use are major determinants of soil microbial community composition and biomass at a regional scale in northeastern China, Biogeosciences, 12, 2585-2596, https://doi.org/10.5194/bg-12-2585-2015, 2015.

Marschner, P., Marino, W., and Lieberei, R.: Seasonal effects on microorganisms in the rhizosphere of two tropical plants in a polyculture agroforestry system in Central Amazonia, Brazil, Biol. Fert. Soils, 35, 68-71, https://doi.org/10.1007/s00374-001-04353, 2002.

Mukhopadhyay, S., Masto, R. E., Cerdà, A., and Ram, L. C.: Rhizosphere soil indicators for carbon sequestration in a reclaimed coal mine spoil, Catena, 141, 100-108, https://doi.org/10.1016/j.catena.2016.02.023, 2016.

Nannipieri, P., Grego, S., and Ceccanti, B.: Ecological significance of the biological activity in soil, Soil Biochemistry, 6, 293-355, https://doi.org/10.1201/9780203739389-7, 1990.

Nilsson, L. O., Giesler, R., Bååth, E., and Wallander, H.: Growth and biomass of mycorrhizal mycelia in coniferous forests along short natural nutrient gradients, New Phytol., 165, 613-622, https://doi.org/10.1111/j.1469-8137.2004.01223.x, 2005.

Qin, Y. Y., Feng, Q., Holden, N. M., and Cao, J. J.: Variation in soil organic carbon by slope aspect in the middle of the Qilian Mountains in the upper Heihe River Basin, China, Catena, 147, 308-314, https://doi.org/10.1016/j.catena.2016.07.025, 2016.

Sariyildiz, T., Anderson, J., and Kucuk, M.: Effects of tree species and topography on soil chemistry, litter quality, and decomposition in Northeast Turkey, Soil Biol. Biochem., 37, 1695-1706, https://doi.org/10.1016/j.soilbio.2005.02.004, 2005.

Selvakumar, G., Joshi, P., Mishra, P. K., Bisht, J. K., and Gupta, H. S.: Mountain aspect influences the genetic clustering of psychrotolerant phosphate solubilizing Pseudomonads 
in the Uttarakhand Himalayas, Curr. Microbiol., 59, 432-438, https://doi.org/10.1007/s00284-009-9456-1, 2009.

Sidari, M., Ronzello, G., Vecchio, G., and Muscolo, A.: Influence of slope aspects on soil chemical and biochemical properties in a Pinus laricio forest ecosystem of Aspromonte (Southern Italy), Eur. J. Soil Biol., 44, 364-372, https://doi.org/10.1016/j.ejsobi.2008.05.001, 2008.

Sinha, S., Masto, R., Ram, L., Selvi, V., Srivastava, N., Tripathi, R., and George, J.: Rhizosphere soil microbial index of tree species in a coal mining ecosystem, Soil Biol. Biochem., 41, 1824-1832, https://doi.org/10.1016/j.soilbio.2008.11.022, 2009.

Tscherko, D., Hammesfahr, U., Marx, M.-C., and Kandeler, E.: Shifts in rhizosphere microbial communities and enzyme activity of Poa alpina across an alpine chronosequence, Soil Biol. Biochem., 36, 1685-1698, https://doi.org/10.1016/j.soilbio.2004.07.004, 2004.

Vance, E. D., Brookes, P. C., and Jenkinson, D. S.: An extraction method for measuring soil microbial biomass C, Soil Biol. Biochem., 19, 703-707, https://doi.org/10.1016/00380717(87)90052-6, 1987

Wang, G. L. and Liu, G. B.: Study on the interspecific association of the artemisia sacrorum community in Loess Hilly Region, Grassland of China, 24, 1-6, https://doi.org/10.3969/j.issn.16735021.2002.03.001, 2002.

Wang, L., Wang, Q., Wei, S., Shao, M. A., and Li, Y.: Soil desiccation for Loess soils on natural and regrown areas, Forest. Ecol. Manag., 255, 2467-2477, https://doi.org/10.1016/j.foreco.2008.01.006, 2008.
Wardle, D. A.: Impacts of disturbance on detritus food webs in agro-ecosystems of contrasting tillage and weed management practices, Adv. Ecol. Res., 26, 105-185, https://doi.org/10.1016/S0065-2504(08)60065-3, 1995.

Warembourg, F., Roumet, C., and Lafont, F.: Differences in rhizosphere carbon-partitioning among plant species of different families, Plant Soil, 256, 347-357, https://doi.org/10.1023/A:1026147622800, 2003.

Zelles, L.: Fatty acid patterns of phospholipids and lipopolysaccharides in the characterisation of microbial communities in soil: a review, Biol. Fert. Soils, 29, 111-129, https://doi.org/10.1007/s003740050533, 1999.

Zhang, C., Liu, G. B., Xue, S., and Zhang, C. S.: Rhizosphere soil microbial properties on abandoned croplands in the Loess Plateau, China during vegetation succession, Eur. J. Soil Biol., 50, 127-136, https://doi.org/10.1016/j.ejsobi.2012.01.002, 2012.

Zhang, C., Liu, G. B., Xue, S., and Wang, G. L.: Changes in rhizospheric microbial community structure and function during the natural recovery of abandoned cropland on the Loess Plateau, China, Ecol. Eng., 75, 161-171, https://doi.org/10.1016/j.ecoleng.2014.11.059, 2015.

Zhang, W., Parker, K., Luo, Y., Wan, S., Wallace, L., and Hu, S.: Soil microbial responses to experimental warming and clipping in a tallgrass prairie, Global Change Biol., 11, 266-277, https://doi.org/10.1111/j.1365-2486.2005.00902.x, 2005. 